\title{
Food additives and food components in total diets in The Netherlands
}

\author{
BY W. VAN DOKKUM, R. H. DE VOS, FRANCES A. CLOUGHLEY, \\ KARIN F. A. M. HULSHOF, F. DUKEL AND J. A. WIJSMAN \\ Division of Nutrition and Food Research TNO, CIVO Institutes, Zeist, The Netherlands
}

(Received 30 November 1981-Accepted 15 March 1982)

1. During a period of 2 years, every 2 months 126 different food items forming a 'market basket ' were purchased, prepared and divided into twelve food commodity groups. The ' market basket' was based on a study of the dietary pattern of 16- to 18-year-old male adolescents. In the (homogenized) food groups various additives and components of nutritional importance were determined. From the concentrations of the additives and components in the food groups and the daily consumption of each food group, a mean daily intake of all components analysed was calculated.

2. The mean daily amounts of benzoic acid $(34 \mathrm{mg})$, sorbic acid $(6 \mathrm{mg})$, glutamic acid $(660 \mathrm{mg})$ and sulphite $(3 \mathrm{mg})$ were all far below the acceptable daily intake (ADI) value. Butylated hydroxytoluene and gallates were not detectable, while butylated hydroxyanisole (BHA) was found in only a few instances; the maximum amount of BHA was also very low $(4 \mathrm{mg})$.

3. The mean daily intakes of fluorine $(0.8 \mathrm{mg})$, iodine $(0.21 \mathrm{mg})$, phosphorus $(1860 \mathrm{mg})$ and $\alpha$-tocopherol $(9.4 \mathrm{mg})$ seem safe and adequate. Cholesterol intakes of $25 \%$ above the maximum of $300 \mathrm{mg} / \mathrm{d}$, as advised by the Dutch Bureau for Nutrition Education, were found. The mean fat intake appeared to be $40 \%$ of total daily energy, protein content $13 \%$ of total energy and total (available) carbohydrate $46 \%$ of total energy. The daily dietary fibre content $(18 \mathrm{~g})$ and the daily amount of linoleic + linolenic acid $(6 \%$ of total energy) were considered too low. The daily level of sodium $(4 \cdot 2 \mathrm{~g})$ was not considered too high.

4. It is recommended that the study should be repeated regularly, e.g. every few years, in order to monitor trends in the concentrations of significant food components in total diets.

The levels of unnatural components in our food are an important aspect of nutritional quality. These components may be described as substances that migrate into or are formed in the foods during production, processing, storage or packaging of the foods and which may be a health hazard when concentrations are too high. The unnatural components include those added for certain reasons (e.g. preservatives) and contaminants (e.g. residues of pesticides and heavy metals).

For a number of additives and contaminants upper concentration limits have been established on the basis of their toxicological properties. From these upper limits, theoretical daily intakes can be calculated, assuming that all daily food items contain maximum tolerable quantities of the various unnatural components. The actual intake presumably will be lower, but for most components these actual intake levels are unknown.

The risk for the consumer can be evaluated by comparing the actual intake (when this is known) with the acceptable daily intake (ADI) (FAO/WHO, 1974).

The FAO/WHO Expert Committee on Pesticide Residues (FAO/WHO, 1976) recommends the study of the various contaminants in total diets. Such a study is defined as follows: 'A total diet study is one designed to show the pattern of pesticide residue intake by a person consuming a typical diet.'

Results of the first study in The Netherlands, regarding food additives and components of nutritional importance, are reported in the present paper. Results with respect to contaminants are reported elsewhere (Vos et al. 1982). 
Table 1. Overall composition of total diets consumed by 16-to 18-year-old Dutch male adolescents

\begin{tabular}{rlr}
\hline \hline $\begin{array}{c}\text { Group } \\
\text { no. }\end{array}$ & \multicolumn{1}{c}{ Food group } & $\begin{array}{c}\text { Average daily } \\
\text { intake }(\mathrm{g} / \mathrm{d})\end{array}$ \\
\hline 1 & Grain and cereal products & 331 \\
2 & Potatoes and potato products & 229 \\
3 & Vegetables and garden fruits & 159 \\
4 & Root vegetables & 28 \\
5 & Legume vegetables & 22 \\
6 & Fruits & 195 \\
7 & Meat, poultry and eggs & 159 \\
8 & Fish & 636 \\
9 & Dairy products & 51 \\
10 & Oils and fats & 81 \\
11 & Sugars, sweets, etc. & 1642 \\
12 & Beverages, including drinking-water & \\
\hline \hline
\end{tabular}

\section{METHODS}

In the present study a 'market basket' approach was chosen. The composition of the 'basket' was patterned according to the average total diet of 16- to 18-year-old male adolescents, based on a food consumption survey in 1974 carried out by CIVO and the Dutch Nutrition Council (unpublished results) in several schools in Amsterdam (cross-check method with emphasis on a 2-week diet) as well as on the consumption information for the Dutch population, published by the (Dutch) Ministry of Agriculture and Fisheries (1974).

Male adolescents probably consume the highest amount of food and consequently the highest amounts of food additives and contaminants as compared to other age categories. An indication of the high food intake are the recommended dietary allowances for this group. The 'market basket' included 126 different food items. During a period of 2 years (1976-78), every 2 months the complete set of foods were purchased in Zeist, a town in the centre of The Netherlands with approximately 60000 inhabitants. Variation regarding shops, markets, etc. as well as brands was intended. In this way seasonal differences were taken into account. A total of twelve sample 'market baskets' were collected. The various foods were prepared in the usual manner for normal consumption. Cleaning, cooking, frying, etc., were done according to standard procedures.

After preparation, the foods were divided into twelve broad groups (Table 1) representing the basic 2-week diet of a 16- to 18-year-old male. Foods in each of these twelve groups were homogenized and frozen at $-20^{\circ}$. Samples from each mixture were analysed for presence of additives, contaminants and food components of nutritional importance.

The food additives in question are presented in Table 2; Table 3 shows the nutrients and several miscellaneous components analysed in the various food groups.

\section{ANALYTICAL PROCEDURES}

Benzoic acid and sorbic acid. These were analysed by gas-liquid chromatography (GLC) (Graveland, 1972) after extraction of the sample with diethyl ether and subsequent methylation with diazomethane (Gosselé, 1971).

Butylated hydroxyanisole (BHA), butylated hydroxytoluene $(B H T)$ and gallates. After chloroform extraction of the fat a qualitative analysis was carried out (IUPAC, 1979). The presence of BHA could be demonstrated in a few instances only. Subsequently a quantitative 
Table 2. Food additives determined in total diets of 16- to 18-year-old Dutch male adolescents

\begin{tabular}{lc}
\hline \multicolumn{1}{c}{ Additive } & Determined in food group no.* \\
\hline Benzoic acid & $1,2,3,6,9,10,11,12$ \\
BHA & $1,2,7,8,10$ \\
BHT & $1,2,7,8,10$ \\
Gallates & $1,2,7,8,10$ \\
Glutamic acid & All groups \\
Sorbic acid & $1,2,3,6,9,10,11,12$ \\
Sulphite & $1,2,3,6,7,9,11,12$ \\
\hline \hline
\end{tabular}

BHA, butylated hydroxyanysole; BHT, butylated hydroxytoluene.

* For details of groups, see Table 1.

Table 3. Food components analysed in total diets of 16- to 18-year-old Dutch male adolescents

\begin{tabular}{ll}
\hline \multicolumn{1}{c}{ Component } & $\begin{array}{c}\text { Determined in food } \\
\text { group no.* }\end{array}$ \\
\hline Protein & All groups \\
Fat & All groups \\
Total (available) carbohydrate & All groups \\
Linoleic acid +linolenic acid & $1,2,7,8,9,10,11$ \\
Dietary fibre & $1,2,3,4,5,6$ \\
Phosphate & All groups \\
Fluorine & All groups \\
Iodine & All groups \\
$\alpha$-Tocopherol & $1,2,4,7,8,9,10$ \\
Cholesterol & $1,2,7,8,9,10,11$ \\
Sodium & All groups \\
\hline \hline
\end{tabular}

* For details of groups, see Table 1.

analysis for BHA was carried out using dichloroquinonchloroimide and borax (IUPAC, 1979).

Glutamic acid. After extraction of free glutamic acid with a $100 \mathrm{ml}$ trichloroacetic acid/1 solution, the concentration was determined using an automated amino acid analyser (Spackman et al. 1958).

Sulphite. After acidification of the sample, the sulphite was distilled in a carbon dioxide atmosphere into a hydrogen peroxide solution; the sulphuric acid formed was titrated with alkali (Reith \& Willems, 1958).

Cholesterol. Cholesterol was analysed by GLC of the sterol-trimethylsilyl ethers after extraction of the unsaponifiable matter of the fat with diethyl ether (IUPAC, 1979).

Protein. Protein was calculated from the Kjeldahl nitrogen determination, using the automated KjellFoss (Noel, 1976), by applying the factor 6.25.

Fat. Fat was analysed according to the Weibull-Stoldt method by extraction of the sample with light petroleum (b.p. 60-80 ) (Schormüller, 1969).

Total (available) carbohydrates. These were determined using pancreatic amylase to transform starch into soluble carbohydrates and subsequent hydrolysis of the carbohydrates with hydrochloric acid to glucose. Glucose and other monomeric sugars were analysed using 
Table 4. Additives in total diets of 16-to 18-year-old Dutch male adolescents

(Means of twelve sample 'market basket' in 2 years)

\begin{tabular}{|c|c|c|c|c|c|c|c|c|}
\hline \multirow[b]{2}{*}{$\begin{array}{l}\text { Food } \\
\text { group } \\
\text { no.* }\end{array}$} & \multicolumn{2}{|c|}{ Benzoic acid } & \multicolumn{2}{|c|}{ Sorbic acid } & \multicolumn{2}{|c|}{ Free glutamic acid } & \multicolumn{2}{|c|}{ Sulphite (as $\mathrm{SO}_{2}$ ) } \\
\hline & $\begin{array}{l}\text { Mean } \\
\text { concen- } \\
\text { tration } \\
(\mathrm{mg} / \mathrm{kg})\end{array}$ & $\begin{array}{c}\text { No. of } \\
\text { positive } \\
\text { samples } \dagger\end{array}$ & $\begin{array}{c}\text { Mean } \\
\text { concen- } \\
\text { tration } \\
(\mathrm{mg} / \mathrm{kg})\end{array}$ & $\begin{array}{c}\text { No. of } \\
\text { positive } \\
\text { samples }\end{array}$ & $\begin{array}{c}\text { Mean } \\
\text { concen- } \\
\text { tration } \\
(\mathrm{mg} / \mathrm{kg})\end{array}$ & $\begin{array}{c}\text { No. of } \\
\text { positive } \\
\text { samples } \dagger\end{array}$ & $\begin{array}{c}\text { Mean } \\
\text { concen- } \\
\text { tration } \\
(\mathrm{mg} / \mathrm{kg})\end{array}$ & $\begin{array}{c}\text { No. of } \\
\text { positive } \\
\text { samples }{ }^{\dagger}\end{array}$ \\
\hline 1 & 8 & 7 & 9 & 9 & 86 & 12 & 2 & 6 \\
\hline 2 & 0 & 0 & $<5$ & 1 & 790 & 12 & $<2$ & 4 \\
\hline 3 & $<5$ & 3 & $<5$ & 3 & 1100 & 12 & $<2$ & 3 \\
\hline 4 & ND & - & ND & - & 290 & 12 & ND & - \\
\hline 5 & ND & - & ND & - & 210 & 12 & ND & - \\
\hline 6 & 0 & 0 & 0 & 0 & 62 & 12 & $<2$ & 3 \\
\hline 7 & ND & - & ND & - & 490 & 12 & 5 & 7 \\
\hline 8 & ND & - & ND & - & 340 & 12 & ND & - \\
\hline 9 & 8 & 7 & $<5$ & 2 & 240 & 12 & $<2$ & 2 \\
\hline 10 & 410 & 12 & 30 & 10 & 240 & 12 & ND & - \\
\hline 11 & 8 & 7 & $<5$ & 2 & 33 & 12 & 6 & 6 \\
\hline 12 & $<5$ & 5 & 6 & 2 & 7 & 12 & $<2$ & 1 \\
\hline
\end{tabular}

ND, not determined.

* For details of groups, see Table 1.

$\dagger$ Maximum of twelve samples.

the Luff-Schoorl reagent (Kamer, 1941). Results were expressed as \% starch; only in group 11 (sugars, sweets) were the results calculated as \% saccharose.

Phosphate. After dry ashing of the sample and dissolving the ash in nitric acid, phosphorus was precipitated using a sulphate-molybdenum reagent. Ammonium phosphorus molybdate was determined gravimetrically (Schormüller, 1967). Results were expressed in $\mathrm{mg} \mathrm{P} / \mathrm{kg}$.

Dietary fibre. Dietary fibre was analysed by means of the method of Hellendoorn et al. (1975).

Linoleic acid and linolenic acid. The acids were determined by GLC of the fatty acid methylesters (IUPAC, 1979).

Fluorine, Samples were dry ashed in an alkaline medium at $450^{\circ}$. After acidification the ash was steam-distilled into an alkaline solution. $F$ was determined colorimetrically (Yamamura et al. 1962)

Sodium. Samples were dry ashed at $500^{\circ}$ and ash dissolved in $\mathrm{HCl}$. Sodium was determined by atomic absorption spectrophotometry.

Iodine. Iodine was determined by neutron activation analysis (Cornelis \& Hoste, 1973). $\alpha$-Tocopherol. After saponification of the sample and extraction with benzene, high performance liquid chromatography was applied to determine $\alpha$-tocopherol (Carpenter, 1979).

\section{RESULTS AND DISCUSSION}

The mean concentrations in the various food groups (classes) of the components examined are presented in Table 4. Table 5 shows the concentrations of some nutrients in the twelve food groups and the mean daily amounts as calculated from Table 1. The total daily amounts of the additives and food components are given in Table 6.

The values for fat, total carbohydrate and protein contents of the twelve food groups 


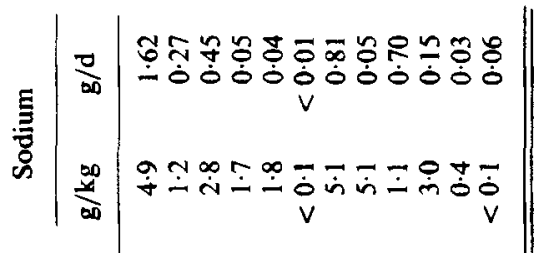


Table 6. Amounts of additives and food components in total diets of 16- to 18-year-old Dutch male adolescents

(Means of twelve sample 'market baskets' in 2 years)

\begin{tabular}{|c|c|c|c|}
\hline \multirow[b]{2}{*}{ Component } & \multicolumn{2}{|c|}{ Daily amounts (mg) } & \multirow{2}{*}{$\frac{\mathrm{ADI}^{*}}{(\mathrm{mg} / \mathrm{d})}$} \\
\hline & Mean content & Max content $\dagger$ & \\
\hline Benzoic acid & 34 & 66 & 300 \\
\hline BHA & $\ddagger$ & 4 & 30 \\
\hline Glutamic acid & 660 & 990 & 7200 \\
\hline Sorbic acid & 6 & 24 & 1500 \\
\hline Sulphite & 3 & 13 & 42 \\
\hline Fluorine & 0.8 & 3 & Unknown \\
\hline Iodine & 0.21 & 0.26 & Unknown \\
\hline Phosphorus & 1860 & 1900 & 4200 \\
\hline Cholesterol & 374 & 760 & 300 \\
\hline$\alpha$-Tocopherol & $9 \cdot 4$ & 14 & 120 \\
\hline
\end{tabular}

* Acceptable daily intake (FAO/WHO, 1974) calculated for a body weight of $60 \mathrm{~kg}$.

$\dagger$ When 'non-detectable' the concentration was assumed to equal the limit of determination.

$\ddagger$ Not calculated as only $10 \%$ of all samples analysed were positive.

are presented in Table 7, while Table 8 gives the total daily amounts of fat, carbohydrate, protein, linoleic acid + linolenic acid, cholesterol and dietary fibre.

The FAO/WHO (1974) acceptable daily intake values for the food additives and a few other components as recalculated for a body weight of $60 \mathrm{~kg}$ are shown in Table 6.

Both the mean and the maximum daily amounts of all components examined were far below the ADI values (Table 6). The highest concentrations of benzoic acid and sorbic acid were found in group 10 (oils and fats), which is probably due to the presence of both components in, for example, margarine.

The sulphite concentrations were relatively high in group 7 (meat, poultry and eggs) and group 11 (sugars, sweets, etc.).

The antioxidant BHA could only be detected in group 8 (fish), BHT was not detectable in any of the samples. Relatively high concentrations of free glutamic acid were found in group 2 (potatoes) and group 3 (vegetables and fruits). In the latter group a high proportion may be attributed to the addition of glutamates to soups, which were included in this group.

The mean daily amount of fluorine was $0.8 \mathrm{mg}$. The highest concentrations were found in group 8 (fish). The (US) National Research Council (1980) considers up to $2.5 \mathrm{mg} / \mathrm{d}$ for adolescents as 'safe and adequate'; the maximum value for $F$ in our study is $3 \mathrm{mg} / \mathrm{d}$. The detection limit of $0.5 \mathrm{mg} / \mathrm{kg}$ for $\mathrm{F}$ seems, however, to be too high to obtain a good estimation of the maximum intake.

The daily $\mathrm{I}_{2}$ allowances are estimated at $0.15 \mathrm{mg}$ (National Research Council, 1980). The calculated mean content of $0.21 \mathrm{mg} / \mathrm{d}$ seems therefore to be adequate, but below the level reported by Harland et al. (1980) in a total diet study in the USA. The highest $I_{2}$ concentrations were found in groups 8 (fish) and 1 (cereals), the latter is probably attributable to the use of iodized salt for baking bread.

The $P$ requirements are reported to be $1200 \mathrm{mg} / \mathrm{d}$ for adolescents (at a level of $1200 \mathrm{mg} / \mathrm{d}$ for calcium) (National Research Council, 1980). FAO/WHO (1974) gives a maximum acceptable daily intake of $4200 \mathrm{mg}$. The mean daily amount of $1860 \mathrm{mg}$ in our study is well below the ADI, but clearly meets requirements. The highest phosphorus values were found in groups 1 (cereals), 7 (meat, poultry and eggs) and 9 (dairy products), a finding which is comparable with US total diets (Harland et al. 1980). 


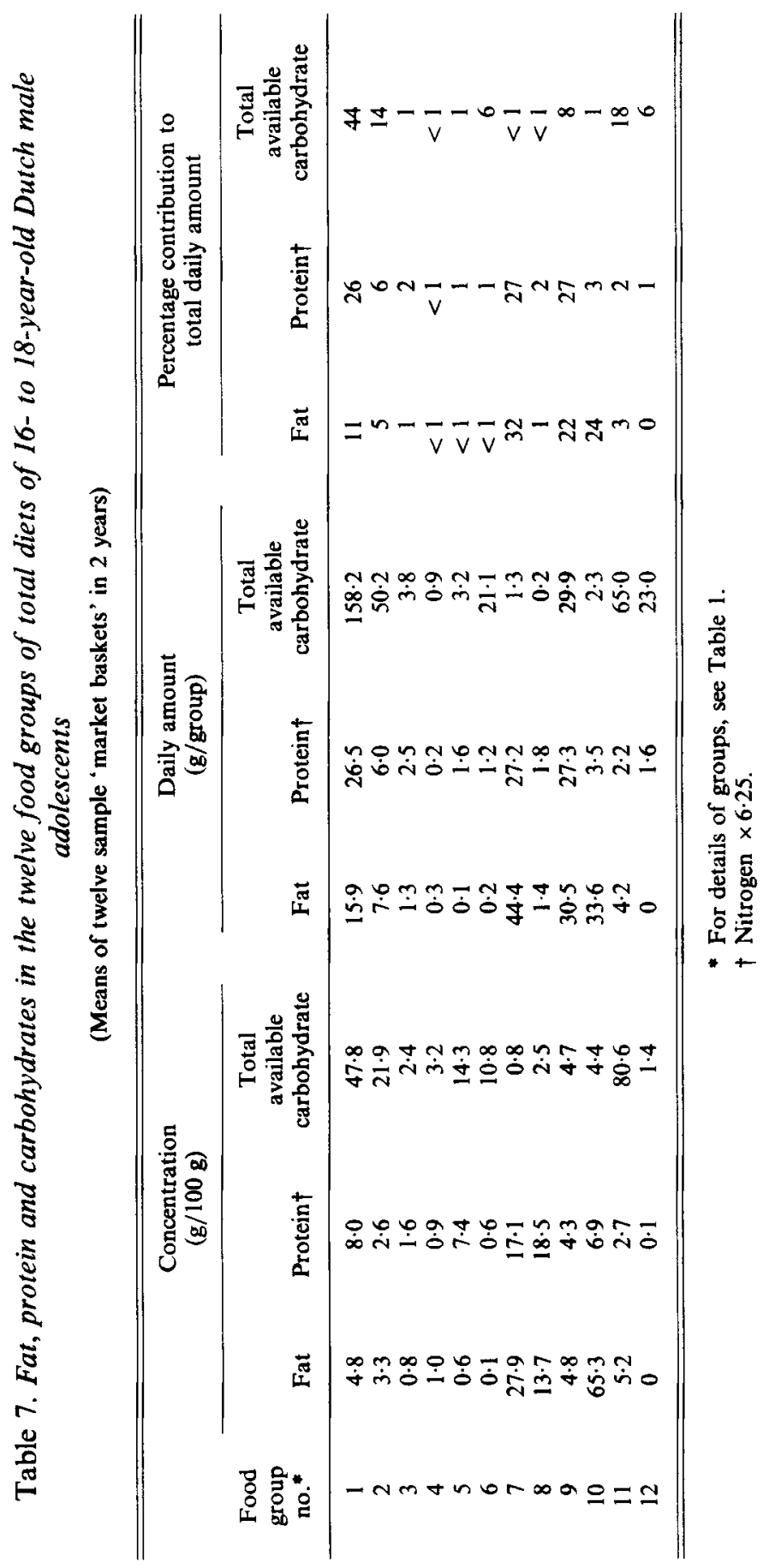


Table 8. Mean daily amounts of some components of nutritional importance in total diets of 16- to 18-year-old Dutch male adolescents

\begin{tabular}{lc}
\hline \multicolumn{1}{c}{ Component } & Mean daily amount \\
\hline Energy (MJ) & 13.0 \\
Fat (g) & 140 \\
Protein (g) & 102 \\
Total available carbohydrate $(\mathrm{g})$ & 359 \\
Fat $(\%$ of energy) & 40.5 \\
Protein (\% of energy) & 13.1 \\
Total available carbohydrate $(\%$ of energy) & 46.4 \\
Linoleic +linolenic acid (g) & 20.4 \\
Linoleic +linolenic acid $\%$ of energy) & 57.9 \\
Cholesterol (mg) & 374 \\
Dietary fibre (g) & 17.7 \\
Dietary fibre (g/4.2 MJ) & 5.7 \\
Sodium (g) & 4.2 \\
\hline
\end{tabular}

The cholesterol intake is advised to be below $250-300 \mathrm{mg} / \mathrm{d}$ in The Netherlands (Dutch Bureau for Nutrition Education, 1978). According to the dietary goals in the USA (Select Committee on Nutrition and Human Needs, US Senate, 1977) a maximum intake of $300 \mathrm{mg} / \mathrm{d}$ is advised. The mean daily level of $374 \mathrm{mg}$ in our study is therefore $25 \%$ higher than the upper limit.

As to the polyunsaturated fatty acids it is advised that the intake should equal one third of the total energy supplied by fat at a total fat intake of $30-40 \%$ of the daily energy intake (Dutch Bureau for Nutrition Education, 1978). The total fat content in our study appears to be approximately $40 \%$ of the total energy intake. The mean level of linoleic acid + linolenic acid was found to be $20.4 \mathrm{~g} / \mathrm{d}$, being only $6 \%$ of total energy or $15 \%$ of total energy supplied by fat.

The daily protein content of $13 \cdot 1 \%$ of total energy intake appears to be at least sufficient; a carbohydrate content of $46 \%$ of total energy as well as a dietary fibre content of $18 \mathrm{~g} / \mathrm{d}$ or $5.7 \mathrm{~g} / 4.2 \mathrm{MJ}$ are considered low. Although to date no recommendations for dietary fibre have been established, it is generally advised to increase the dietary fibre intake in the Western world.

The mean daily amount of $\alpha$-tocopherol was $9.4 \mathrm{mg}$. Because $\alpha$-tocopherol functions, for example, as an antioxidant, the daily requirements are related to the polyunsaturated fatty acid intake. It is recommended that the $\alpha$-tocopherol intake should equal $3 \mathrm{mg} / 4 \cdot 2 \mathrm{MJ}$ in a diet containing up to $10 \%$ of total energy as linoleic acid (Jager, 1973).

The mean daily energy intake of $13 \cdot 1 \mathrm{MJ}$ shows the requirements to be $9 \cdot 3 \mathrm{mg} / \mathrm{d}$, which is very similar to the $9.4 \mathrm{mg} \alpha$-tocopherol as found in our study.

The daily $\mathrm{Na}$ content of the total diet was found to be $4.2 \mathrm{~g}$ (10.5 g sodium chloride), which equals the average $\mathrm{NaCl}$ intake in the USA (Food and Nutrition Board, 1980). The highest levels were found in groups 1 (cereals), 3 (vegetables and fruits), 7 (meat, poultry and eggs) and 9 (dairy products). Standard procedures of cooking, frying, etc. of various food items included the addition of 'normal' amounts of $\mathrm{NaCl}$. The US lower level of the estimated safe and adequate intake for $\mathrm{Na}$ is equivalent to $3 \mathrm{~g} \mathrm{NaCl} / \mathrm{d}$ and the upper level is $8-9 \mathrm{~g} \mathrm{NaCl} / \mathrm{d}$, in addition to the non-discretionary salt intake in foods of at least $3 \mathrm{~g} / \mathrm{d}$ (Food and Nutrition Board, 1980).

The twelve sample total diets were collected every 2 months; statistical analysis did not, however, show a significant relation between the period of sampling and the concentrations of the additives or food components. 
Since the concentration of additives in the average total diets of 16- to 18-year-old males appeared to be low, it can be concluded that for other age categories, consuming relatively less food, the situation is even more favourable.

It should be realized that in a total diet study with a 'market basket' approach the mean concentrations are taken into account. Individual and group variations of food consumption patterns may lead to daily amounts different from those found in our study; the consequences for the concentrations of additives and food components can be estimated by varying the relative contributions of the twelve food groups in the total diets. When the consumption pattern is more extreme, the concentrations of the various components in the single food items in each group should be known.

It is recommended that the present study should be repeated at intervals in order to observe any trends in the risks involved in possible changes in consumption patterns. Changes in policy about food additives both by Industry and the Government would also make it necessary to carry out total diet studies regularly.

The authors wish to thank Dr J. H. L. Zwiers and his co-workers (Division of Technology for Society TNO) for carrying out the iodine determinations.

\section{REFERENCES}

Carpenter, A. P. (1979). J. Am. Oil. Chem. Soc. 56, 668.

Cornelis, R. \& Hoste, J. (1973). J. Radioanalyt. Chem. 13, 419.

Dutch Bureau for Nutrition Education (1978). Food Table and Recommended Dietary Allowances. The Hague: Dutch Bureau for Nutrition Education.

FAO/WHO (1974), WHO Food. Add. Ser. no. 5.

FAO/WHO (1976). WHO Tech. Rep. Ser. no. 592.

Food and Nutrition Board (1980). Toward Healthful Diets. Washington DC: National Academy of Sciences.

Gosselé, J. A. W. (1971). J. Chromat. 63, 429.

Graveland, A. (1972). J. Ass. Off. Analyt. Chem. 55, 1024.

Harland, B. F., Johnson, R. D., Blendermann, E. M., Prosky, L., Vanderveen, J. E., Reed, G. L., Forbes, A. L. \& Roberts, H. R. (1980). J. Am. Diet. Ass. 77, 16.

Hellendoorn, E. W., Noordhoff, M. G. \& Slagman, J. (1975). J. Sci. Fd Agric. 26, 1461

IUPAC (1979). Standard Methods. Oxford: Pergamon Press.

Jager, F. C. (1973). Linoleic acid intake and vitamin E requirements. PhD Thesis, Agricultural University Wageningen.

Kamer, J.v.d. (1941). Chem. Weekbl. 38, 286.

Ministry of Agriculture and Fisheries (1974). Food Consumption in The Netherlands. The Hague: Department of Statistics and Documentation.

National Research Council (1980). Recommended Dietary Allowances. Washington DC: National Academy of Sciences.

Noel, R. J. (1976). J. Ass. Off. Analyt. Chem. 59, 141.

Reith, J. F. \& Willems, J. J. L. (1958). Z. Lebensm. Unters. 108, 270.

Schormüller. J. (1967). Handbuch der Lebensmittelchemie, vol. 2, p. 77. Berlin: Springer Verlag.

Schormüller, J. (1969). Handbuch der Lebensmittelchemie, vol. 4, p. 423. Berlin: Springer Verlag.

Select Committee on Nutrition and Human Needs, US Senate (1977). Dietary Goals for the United States, 2nd ed. Washington DC: Government Printing Office.

Spackman, D. H., Stein, W. H. \& Moore, S. (1958). Analyt. Chem. 30, 1190.

Vos, R. H. de, Dokkum, W. v., Olthof, P. D. A., Quirijns, J. W., Muys, T. \& Poll, J. M. v. d. (1982). Pestic. Monit. $J$. (In the Press).

Yamamura, S. S., Wade, M. A. \& Sikes, J. H. (1962). Analyt. Chem. 34, 1308. 